\title{
90th Growth Percentile
}

National Cancer Institute

\section{Source}

National Cancer Institute. 90th Growth Percentile. NCI Thesaurus. Code C98266.

An indication that an individual ranks the same or more than 90 percent (top 10 percent)

of the reference population for a given attribute. 